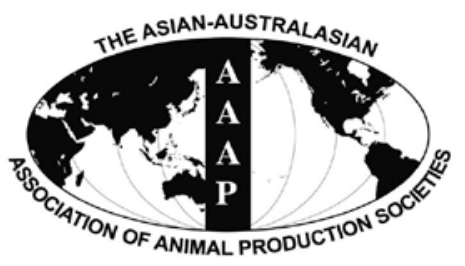

Asian-Aust. J. Anim. Sci.

Vol. 25, No. 2 : 207 - 212

February 2012

www.ajas.info

http://dx.doi.org/10.5713/ajas.2011.11261

\title{
Contribution of Urine and Dung Patches from Grazing Sheep to Methane and Carbon Dioxide Fluxes in an Inner Mongolian Desert Grassland
}

\author{
Yuanyuan Jiang, Shiming Tang, Chengjie Wang ${ }^{\mathrm{a}, *}$, Pei Zhou, Mario Tenuta ${ }^{1}$, Guodong Han and Ding Huang ${ }^{2, a}$ \\ College of Ecology and Environment, Inner Mongolia Agricultural University, Huhhot 010019, China
}

\begin{abstract}
The effects of sheep urine and dung patches on methane $\left(\mathrm{CH}_{4}\right)$ and carbon dioxide $\left(\mathrm{CO}_{2}\right)$ fluxes were investigated during the summer-autumn in 2010, to evaluate their contribution to climate change in a desert grassland in Inner Mongolia, China. Results indicate that the cumulative $\mathrm{CH}_{4}$ emissions for dung patches, urine patches and control plots were $-0.076,-0.084$, and -0.114 $\mathrm{g} / \mathrm{m}^{2}$ and these were net $\mathrm{CH}_{4}$ sinks during the measured period. The level of $\mathrm{CH}_{4}$ intake from urine and dung plots decreased $25.7 \%$, and $33.3 \%$, respectively, compared with a control plot. $\mathrm{CO}_{2}$ fluxes differed $(\mathrm{p}<0.01)$ in urine plots, with an average of $569.20 \mathrm{mg} / \mathrm{m}^{2} / \mathrm{h}$ compared with control plots $\left(357.62 \mathrm{mg} / \mathrm{m}^{2} / \mathrm{h}\right.$ ) across all sampling days. Dung patches have cumulative $\mathrm{CO}_{2}$ emissions that were $15.9 \%$ higher compared with the control during the 55-d period. Overall, sheep excrement weakened $\mathrm{CH}_{4}$ intake and increased $\mathrm{CO}_{2}$ emissions. (Key Words : Sheep, Urine and Dung Patches, $\mathrm{CO}_{2}$ and $\mathrm{CH}_{4}$ Fluxes, Greenhouse Effect, Inner Mongolia Desert Grassland)
\end{abstract}

\section{INTRODUCTION}

Greenhouse gas (GHG) exchange in the soil-atmosphere of terrestrial ecosystems has an important effect on global climate change. China has the world's second largest grassland area, with grasslands covering 400 million hectares or $42 \%$ of total land area. Of this area, 87 million hectares is within the province of Inner Mongolia. Grazing by sheep (Ovis aries), beef cattle (Bos taurus), and goat (Capra hircus) is the main agricultural activity in the Inner Mongolia grassland. Livestock can be an important source of methane $\left(\mathrm{CH}_{4}\right)$ through direct enteric emissions and decomposition of excreta deposited on grassland (Kulling et al., 2003; Muhammad et al., 2008). Annual $\mathrm{CH}_{4}$ emission is approximately $535 \mathrm{Tg}(410-660 \mathrm{Tg})\left(1 \mathrm{Tg}=10^{12} \mathrm{~g}\right)$ worldwide with $85 \mathrm{Tg}$ (65-100 Tg) from livestock (IPCC, 2001). In the grazed grassland ecosystems, nutrient cycles

\footnotetext{
* Corresponding Author : Chengjie Wang. Tel: +86-471-4301371, Fax: +86-471-4301371, E-mail: cjwang3@sohu.com

${ }^{1}$ Department of Soil Science, University of Manitoba, Winnipeg, Manitoba, Canada R3T 2N2.

${ }^{2}$ Institute of Grassland Science, China Agricultural University, Beijing 100094, China.

${ }^{a}$ Ding Huang and Chengjie Wang contributed equally to this work.
}

Received August 4, 2011; Accepted November 6, 2011 are strongly affected by grazing livestock, and much consumed nutrients are returned in the form of dung and urine, which alters soil conditions for $\mathrm{CH}_{4}$ fluxes (Haynes and Williams, 1993).

Estimates of $\mathrm{CH}_{4}$ emissions have been obtained for temperate grasslands (Wang et al., 2009) and alpine meadows of the Qinghai-Tibetan Plateau (Pei et al., 2003) but animal excreta effects were not considered. Feces and urine voided by grazing livestock can give rise to 'hotspots' of GHG production. These 'hotspots' represent high local additions of readily available carbon (C) resulting in surface emissions of carbon dioxide $\left(\mathrm{CO}_{2}\right)$ and $\mathrm{CH}_{4}$ (Clemens and Ahlgrimm, 2001; Roland et al., 2004; Saggar et al., 2004; Cardenas et al., 2007). The focus of much research on the effect of excreta on GHG emissions has largely been on cattle urine or dung (Haynes and Williams, 1992, 1993; Flessa et al., 1996; Lovell and Jarvis, 1996; Flessa and Beese, 2000). Sheep and cattle excreta patches are different in nature by the area covered, nutrient concentration in soil, and the height of fall of excreta (Williams and Haynes, 1994). Reports of GHG emissions from sheep dung and urine are few, but with some notable exceptions (Shand et al., 2002; Saggar et al., 2004). In China, Ma et al. (2006) reported emissions from sheep excreta from typical steppe grassland in Inner Mongolia. In addition to typical steppe, meadow steppe and desert steppe comprise the dominant 
grassland types in Inner Mongolia. GHG emissions from livestock excreta have not been examined in the latter two grassland types.

The objective of this study was to determine the shortterm effects of dung and urine patches from sheep on $\mathrm{CH}_{4}$ and $\mathrm{CO}_{2}$ emissions in a desert steppe. In addition, the relation of composition of excreta to emissions was determined. Finally, the results are discussed in relation to the potential contribution of GHG emissions from livestock excreta in the Inner Mongolian desert grassland.

\section{MATERIALS AND METHODS}

\section{Site description}

This study was conducted from August through October 2010, at an experimental site at the Inner Mongolia Academy of Agriculture and Animal Husbandry Research Station (111 $\left.53^{\prime} 46^{\prime \prime} \mathrm{E}, 41^{\circ} 47^{\prime} 17^{\prime \prime} \mathrm{N}\right)$. The site has an elevation of $1,450 \mathrm{~m}$ and is in a temperate continental climate, characterized by a short growing season and long cold winter with a frost-free period of $175 \mathrm{~d}$. January is the coldest month with an average temperature of $-15.1^{\circ} \mathrm{C}$ while July is the warmest month with an average temperature of $19.6^{\circ} \mathrm{C}$. The average annual precipitation is approximately $280 \mathrm{~mm}$, of which nearly $75 \%$ falls during June through September. Monthly rainfall was 188, 184 and $59 \mathrm{~mm}$ for August, September and October 2010, respectively (Figure 1). Mean monthly temperature was 18, 13 and $5^{\circ} \mathrm{C}$ for August, September and October 2010, respectively (Figure 1).

The grassland is dominated by Stipa breviflora Griseb, Artemisia frigida Willd, Cleistogenes songorica (Roshev) Ohwi, and accompanied by Convolvulus ammannii Desr, Heteropappus altaicus (Willd) Novopokr, Neopallasia petinata (Pall) Poljak, Bassia prostrate (L.) A. J. Scott, Caragana stenophylla Pojark, Leymus chinensis (Trin) Tzvelev. Mean vegetation properties from $50 \times 50 \mathrm{~cm}$

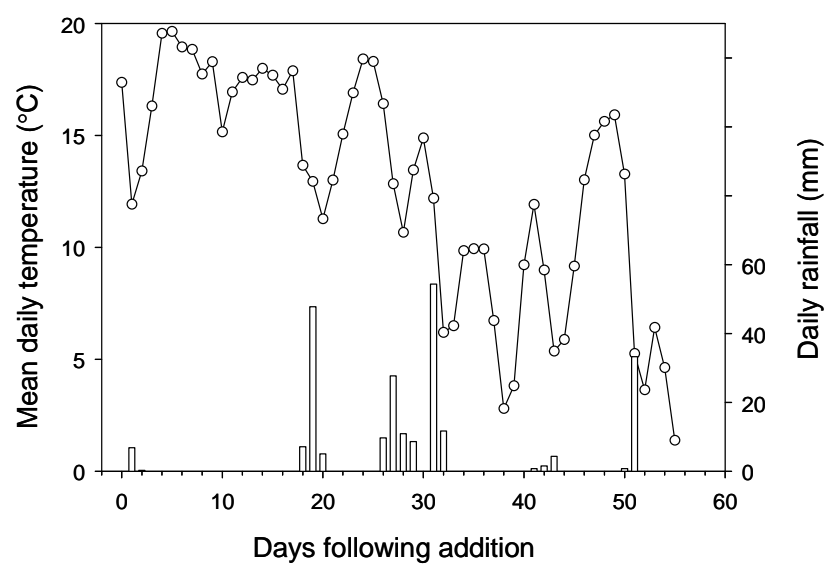

Figure 1. Daily mean air temperature and rainfall during the study. quadrats $(n=5)$ at the site were: plant cover of $19 \%$, average height of $5.6 \mathrm{~cm}$, and a density of 13 plant clusters $/ \mathrm{m}^{2}$. Above ground biomass averaged $95 \mathrm{~g} / \mathrm{m}^{2}$. Mean soil properties for the 0 to $15 \mathrm{~cm}$ depth from the quadrats was $\mathrm{pH}\left(\mathrm{H}_{2} \mathrm{O}: \mathrm{Siol}=5: 1\right)$ 8.3, soil organic matter $41.8 \mathrm{~g} / \mathrm{kg}$, total organic nitrogen $0.92 \mathrm{~g} / \mathrm{kg}, \mathrm{NO}_{3}{ }^{-}-\mathrm{N} 8.0 \mathrm{mg} / \mathrm{kg}$, and $2 \mathrm{M}$ $\mathrm{KCl}-\mathrm{NH}_{4}{ }^{+}-\mathrm{N} 6.1 \mathrm{mg} / \mathrm{kg}$.

\section{Experimental design}

The experiment was conducted from 20 August to 14 October 2010. A complete randomized block design was used with three treatments of urine, dung and no addition (control) with three replicate plots. The dimension of each plot was $50 \times 50 \mathrm{~cm}$.

Sheep dung and urine were collected from 70 animals on 20 August 2010 in metabolism cages and were separately mixed and added to the plots. Prior to placement in the metabolism cages, the animals had grazed the vegetation at the site. The dung had a dry matter content of $85 \%$, ash content of $30 \%$, acid detergent fiber content of $35 \%$, neutral detergent fiber $50.3 \%$ and crude fat $6.21 \%$. The urine had a total $\mathrm{N}$ content of $10 \mathrm{~g} / \mathrm{L}$ and urea $4.7 \mathrm{~g} / \mathrm{L}$. The freshly collected urine and dung were applied at rates of $550 \mathrm{ml}$ and $380 \mathrm{~g}$, respectively, to each plot $\left(0.25 \mathrm{~m}^{2}\right)$ based on deposition rates for each excretion product (Ma et al., 2006). Control plots received only $550 \mathrm{ml}$ of deionized water. A watering can was used to apply the urine from a height of $50 \mathrm{~cm}$ above the ground to simulate sheep urination, and the dung was applied onto the plot surface by hand spreading.

\section{Measurements}

Fluxes of $\mathrm{CH}_{4}$ and $\mathrm{CO}_{2}$ were measured using the closed static chamber method (Wang and Wang, 2003). The chamber had a dimension of $50 \times 50 \times 50 \mathrm{~cm}$ made of stainless steel. The chamber was placed on a steel base frame driven $10 \mathrm{~cm}$ into each plot one day prior to the start of the experiment. The base frame had a channel in which the chamber was inserted and the channel was filled with water to seal the chamber atmosphere. A 9 VDC fan was fixed in to the top wall of each chamber to mix the chamber atmosphere. The temperature of the atmosphere in the chamber and soil at $5 \mathrm{~cm}$ were determined using thermocouples and a hand-held reader (HH-25TC, OMEGA Engineering Inc., Stamford, USA). The chamber was covered with a shroud made of camel hair, aluminum foil and white canvas to limit heating of the chamber atmosphere during sampling.

During gas flux determination, a disposable syringe (100 ml) with a 3-way valve was used to collect $200 \mathrm{ml}$ of chamber atmosphere into a sample gas bag (Dalian Hede Technologies Co., Ltd., Dalian, China) at a 10 min interval over a 30 min period. The gas samples were taken three 
times during the first four days at 10:00, 16:00, and 23:00 h, and then once a day between 10:00 to $13: 00 \mathrm{~h}$. The concentrations of $\mathrm{CO}_{2}$ and $\mathrm{CH}_{4}$ in the gas samples were analyzed using a cavity ring-down spectrophotometer (Picarro G1301, Santa Clara, USA). Gas fluxes were calculated using the following equation:

$$
F=\frac{\rho \cdot V \cdot \Delta \mathrm{c}}{A \cdot \Delta \mathrm{t}}
$$

where $F$ is the flux $\left(\mathrm{mg} / \mathrm{m}^{2} / \mathrm{h}\right)$ of $\mathrm{CO}_{2}$ or $\mathrm{CH}_{4} ; \rho$ is the density of 1 mole $\mathrm{CO}_{2}$ or $\mathrm{CH}_{4}$ gas $\left(\mathrm{kg} / \mathrm{m}^{3}\right) ; \Delta \mathrm{c} \Delta \mathrm{t}^{-1}$ is the rate of change in gas concentration $\mathrm{h}^{-1} ; V$ and $A$ are the volume $\left(\mathrm{m}^{3}\right)$ and the chamber base area $\left(\mathrm{m}^{2}\right)$, respectively.

\section{Statistical analysis}

The fluxes of $\mathrm{CH}_{4}$ and $\mathrm{CO}_{2}$ were analyzed using a repeated measures mixed model with treatment, sampling occasion and treatment×occasion as fixed effects, plot as a random and repeating effect with sample occasion using the MIXED procedure of the Statistical Package for Social Science (SPSS 13.0 for Windows, 2003). The model providing the best-fit covariance structure included compound symmetry. The statistical model used was as follows:

$$
y_{i j k}=\mu+\mathrm{T}_{i}+\mathrm{R}_{i j}+\mathrm{P}_{k}+(\mathrm{T} \times \mathrm{P})_{i k}+\mathrm{e}_{i j k}
$$

where $y_{i j k}$ is the response on sample occasion $k$ for plot $j$ $(j=1-3)$ in treatment group $i(i=1-3) ; \mu$ is the overall mean; $\mathrm{T}_{i}$ is the fixed effect of treatment $i ; \mathrm{R}_{i j}$ the random effect of plot $j$ in treatment $i ; \mathrm{P}_{k}$ is the fixed effect of sampling occasion $k$; $(\mathrm{T} \times \mathrm{P})_{i k}$ is the fixed interaction effect of treatment $i$ with sample occasion $k$; $\mathrm{e}_{i j k}$ is the random error for sample occasion $k$ for plot $j$ in treatment group $i$. Significant differences in treatment means were determined using the least significant difference (LSD) statistic ( $\mathrm{p}=$ 0.05).

\section{RESULTS}

\section{Methane and respiration}

Methane flux from urine and dung plots was greater $(p<0.01)$ than from the control plot during the whole study period (Table 1). On the first day of application (Period 1) dung plots emitted significantly different $(\mathrm{p}<0.05)$ amounts of $\mathrm{CH}_{4}$ from other treatments (the peak rate was 161.44 $\mu \mathrm{g} / \mathrm{m}^{2} / \mathrm{h}$ on the first day of dung application). After five hours, dung patches became a weak net $\mathrm{CH}_{4}$ sink and had a weak release on d 4 and d 55 (Figure 1). From d 2 to d 18 (Period 2) and d 22 to d 55 (Period 3), there were similar patterns of variation in all treatments and $\mathrm{CH}_{4}$ fluxes were not significantly different.

$\mathrm{CO}_{2}$ emission rates were affected $(\mathrm{p}<0.01)$ by treatment, sampling day and their interactions during the whole study period (Table 1). During period $1, \mathrm{CO}_{2}$ emission rates were affected $(\mathrm{p}<0.05)$ by treatment, sampling day and their interactions. After application, $\mathrm{CO}_{2}$ emission increased in $<1$ h compared with other times in all of the treatments. The second $\mathrm{CO}_{2}$ emissions peak (591.49, 810.09 and 413.51 $\mathrm{mg} / \mathrm{m}^{2} / \mathrm{h}$ in dung, urine and control plots, respectively) was found at h 47 , which were 1.4 and 2 times greater than that

\begin{tabular}{|c|c|c|c|c|c|}
\hline Gas & Factor & Period 1 & Period 2 & Period 3 & All \\
\hline \multirow{3}{*}{$\begin{array}{l}\mathrm{CH}_{4} \\
\quad\left(\mu \mathrm{g} / \mathrm{m}^{2} / \mathrm{h}\right)\end{array}$} & Control & $-55.3 \pm 6.6^{\mathrm{a}}$ & $-86.9 \pm 5.6$ & $-75.5 \pm 9.9$ & $-79.8 \pm 4.5^{\mathrm{a}}$ \\
\hline & Dung & $38.8 \pm 12.2^{\mathrm{b}}$ & $-77.0 \pm 8.5$ & $-35.6 \pm 6.6$ & $-51.1 \pm 9.7^{\mathrm{b}}$ \\
\hline & Urine & $-29.6 \pm 11.0^{\mathrm{a}}$ & $-73.7 \pm 5.9$ & $-49.2 \pm 8.5$ & $-61.6 \pm 4.8^{\mathrm{b}}$ \\
\hline \multirow{3}{*}{$\begin{array}{l}\mathrm{CO}_{2} \\
\left(\mathrm{mg} / \mathrm{m}^{2} / \mathrm{h}\right)\end{array}$} & Control & $466.7 \pm 91.4^{\mathrm{a}}$ & $370.0 \pm 16.8$ & $82.8 \pm 23.7$ & $357.6 \pm 20.6^{\mathrm{a}}$ \\
\hline & Dung & $695.2 \pm 114.8^{\mathrm{a}}$ & $406.9 \pm 19.8$ & $127.3 \pm 40.5$ & $420.2 \pm 34.8^{\mathrm{a}}$ \\
\hline & Urine & $1,878.5 \pm 315.6^{b}$ & $400.2 \pm 29.9$ & $126.1 \pm 7.4$ & $569.2 \pm 120.9^{\mathrm{b}}$ \\
\hline \multicolumn{6}{|l|}{ Probability $F$} \\
\hline \multirow[t]{4}{*}{$\mathrm{CH}_{4}$} & Model & 0.010 & $<0.0001$ & NS & $<0.0001$ \\
\hline & Time & 0.025 & $<0.0001$ & NS & $<0.0001$ \\
\hline & Treatment & 0.013 & NS & NS & $<0.0001$ \\
\hline & Interaction & NS & NS & NS & 0.0360 \\
\hline \multirow[t]{4}{*}{$\mathrm{CO}_{2}$} & Model & 0.001 & $<0.0001$ & NS & $<0.0001$ \\
\hline & Time & 0.001 & $<0.0001$ & NS & $<0.0001$ \\
\hline & Treatment & 0.015 & NS & NS & 0.0030 \\
\hline & Interaction & 0.016 & 0.0110 & NS & $<0.0001$ \\
\hline
\end{tabular}

Table 1. Mean $\mathrm{CH}_{4}$ and $\mathrm{CO}_{2}$ flux (mean $\pm \mathrm{SE}$ ) for control, dung and urine treatments for three periods and the whole study period (All)

The negative values of $\mathrm{CH}_{4}$ flux express uptake by soil.

Different letters indicate difference $(\mathrm{p}<0.05)$ in mean flux for a gas using the LSD test. NS, $\mathrm{p}>0.05$. 
of the control treatment, respectively (Figure 2).

$\mathrm{CO}_{2}$ flux differed $(\mathrm{p}<0.01)$ in the urine and control plots during the whole study period and during period 1 , but there were no significant differences in period 2 and period 3 . The average $\mathrm{CO}_{2}$ flux for urine and control treatments across all sampling days were 569.20 and $357.62 \mathrm{mg} / \mathrm{m}^{2} / \mathrm{h}$, respectively (Table 1 ). Urine patches showed a $\mathrm{CO}_{2}$ emissions peak at $4,575.35 \mathrm{mg} / \mathrm{m}^{2} / \mathrm{h}$ immediately after application.

\section{Cumulative $\mathrm{CO}_{2}$-C equivalent emission}

The cumulative $\mathrm{CH}_{4}$ emission for dung patches, urine patches and control plots were net $\mathrm{CH}_{4}$ sinks (-0.076, -0.084 and $-0.114 \mathrm{~g} / \mathrm{m}^{2}$, respectively) (Table 2) during the measured period of $55 \mathrm{~d}$ following one excreta event. This indicates a decrease of 25.7 and 33.3\% for urine, and dung plots compared with the control. Field cumulative $\mathrm{CH}_{4}$ fluxes were $-0.053,-0.115$ and $-1,140 \mathrm{~g} / \mathrm{ha}$ from urine, dung plots and control plots, respectively. During the 55-d study period, field cumulative $\mathrm{CH}_{4}$ fluxes were -1.758 , -4.104 and $-33,225.751 \mathrm{~g} / \mathrm{ha}$ from urine, dung plots and control plots, respectively (Table 2).

The average $\mathrm{CO}_{2}$ and cumulative emissions from dung patches increased $15.9 \%$ compared with the control during the 55-d measured period following just one excretion event (Table 2). The dung patches had a greater effect on global warming potentials than urine patches in the Inner Mongolian desert grassland.

\section{DISCUSSION}

\section{Methane and respiration}

Ma et al. (2006) reported that fresh dung and urine plots decreased significantly $(\mathrm{p}<0.05)$ the cumulative $\mathrm{CH}_{4}$ consumption of typical grassland in Inner Mongolia, but their figures were slightly lower than our research results. Plant biomass and stem density might affect $\mathrm{CH}_{4}$ emissions, which correlates with not only clipped plants (Cheng et al., 2007) but also air temperature (Kaharabata et al., 1998; Massé et al., 2003), and manure temperature (Husted, 1994; Park et al., 2006). Simona and Angelo (2005) also found

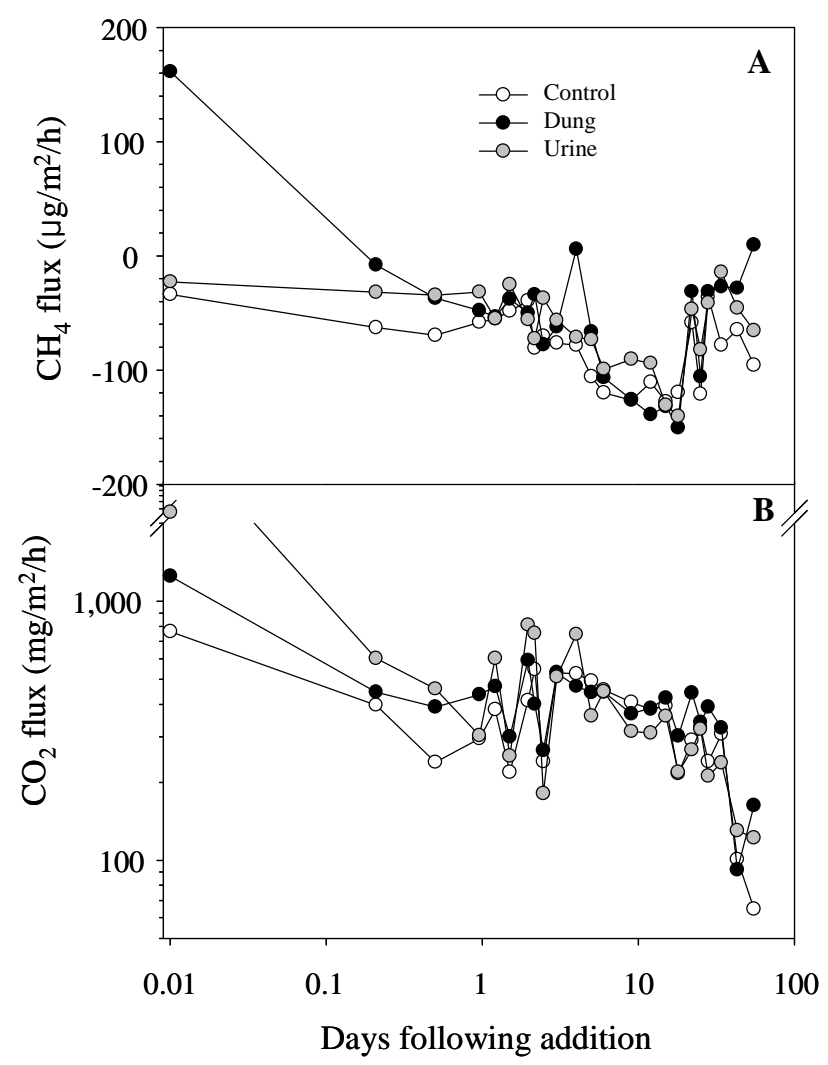

Figure 2. Mean $\mathrm{CH}_{4}$ and $\mathrm{CO}_{2}$ flux from urine, dung, and control plots $(n=3)$. The negative values of $\mathrm{CH}_{4}$ flux express uptake by soil.

that soil water content and temperature were the main factors driving $\mathrm{CH}_{4}$ fluxes. In the driest season, low water content and higher temperature probably stimulated microbial activity, and even landscape position and biogeochemical disturbances may be primary factors affecting $\mathrm{CH}_{4}$ fluxes (Gulledge and Schimel, 2000). The main cause of the difference between our result and those of others may be the differences in climatic and geographical position between desert grassland and typical grassland.

$\mathrm{CH}_{4}$ consumption in sheep excreta patches was greater in this study than in yak excreta patches in the QinghaiTibetan plateau (Lin et al., 2009). $\mathrm{CH}_{4}$ consumption in lowelevation soil increased compared with high-elevation; and

Table 2. Cumulative respiration and $\mathrm{CH}_{4}$ emission, net emission and cumulative $\mathrm{CH}_{4}-\mathrm{CO}_{2}$ equivalent emission potentials over the 55-d study period

\begin{tabular}{|c|c|c|c|c|c|c|c|c|}
\hline Treatment & $\begin{array}{l}\text { Cumulative } \\
\text { resp. }\end{array}$ & $\begin{array}{l}\text { Net } \\
\text { resp. }\end{array}$ & $\begin{array}{c}\text { Field resp. } \\
\text { emission }\end{array}$ & $\begin{array}{c}\text { Cumulative } \\
\mathrm{CH}_{4}\end{array}$ & Net $\mathrm{CH}_{4}$ & $\begin{array}{l}\text { Field } \mathrm{CH}_{4} \\
\text { emission }\end{array}$ & $\mathrm{CH}_{4} \mathrm{CO}_{2}$ eq. & $\begin{array}{c}\text { 55-d field } \mathrm{CH}_{4} \\
\text { emission }\end{array}$ \\
\hline & \multicolumn{2}{|c|}{------ g CO $\mathrm{CO}_{2} / \mathrm{m}^{2}$------ } & $\mathrm{kg} \mathrm{CO} / \mathrm{ha}$ & \multicolumn{2}{|c|}{ 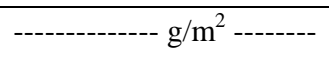 } & - & ---- g/ha --- & 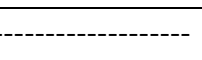 \\
\hline Urine & 349 & 3 & 0.22 & -0.084 & 0.029 & -0.053 & -1.219 & -1.758 \\
\hline Dung & 401 & 55 & 0.61 & -0.076 & 0.038 & -0.115 & -2.645 & -4.104 \\
\hline Control & 346 & - & 3,459 & -0.114 & - & $-1,140$ & $-26,220$ & $-33,225.751$ \\
\hline
\end{tabular}

The negative values of $\mathrm{CH}_{4}$ flux express uptake by soil.

Based on global warming potential factors of 23 for $\mathrm{CH}_{4}$ compared with $\mathrm{CO}_{2}$, and calculated using GHG cumulative emission values (IPCC, 2001). 
mean annual temperature could impact on soil-atmosphere trace gas exchanges, and soil microbial communities (Hart, 2006). However, Lin et al. (2009) reported that dung patches were a strong $\mathrm{CH}_{4}$ source, which was different from our study. Probable reasons are that there are different nutrient transformation characteristics for sheep and yak dung patches which depend on the covered area, nutrient concentration, and differences in shape between sheep and yak feces.

$\mathrm{CH}_{4}$ emissions occurred at d 4 and d 55 in this study. Gulledge and Schimel (2000) reported that nitrogen (N) fertilization inhibited $\mathrm{CH}_{4}$ consumption, a similar result, and Lin et al. (2009) found the combined effect of adding water and $\mathrm{N}$ was to increase $\mathrm{CH}_{4}$ production and decrease $\mathrm{CH}_{4}$ consumption in urine patches. Increased $\mathrm{CH}_{4}$ emissions were also correlated with rainfall events, being about 1.2-4 times higher than prior to and following the rainfall event (Kaharabata et al., 1998). Compared to other sites reported in the literature, in desert grasslands, rainfall is less, soil gas permeability is good and $\mathrm{CH}_{4}$ oxidation rates are high. Further research is needed on the relationship between $\mathrm{CH}_{4}$ uptake and hydrothermic factors.

$\mathrm{CO}_{2}$ emissions increased in urine and control plots in our study. In many similar studies, after urine application a jump in $\mathrm{CO}_{2}$ emissions has been found (Bol et al., 2004; Petersen et al., 2004; Lin et al., 2009). The short jump in $\mathrm{CO}_{2}$ might be due to stimulating microbial respiration (Chadwick and Pain, 1997) or urea hydrolysis to $\mathrm{CO}_{2}$ (Saggar et al., 2004). For feces, the $\mathrm{CO}_{2}$ emissions were from heterotrophic respiration, which is an aerobic microbial process (Billings and Ziegler, 2008) regulated by oxygen availability, and usually determined by moisture content (Bauer et al., 2008). Rapid formation of a crust on fresh dung in warm and dry conditions may create anoxic conditions and $\mathrm{CO}_{2}$ production stops. Gulledge and Schimel (2000) reported that only $\mathrm{N}$ fertilization had an increasing effect on $\mathrm{CO}_{2}$ fluxes, which was significantly positively correlated with the content of the soil organic $\mathrm{C}$ content, the content of soil total N, and the C/N ratio (Geng et al., 2001). However, there was no significant difference between cumulative $\mathrm{CO}_{2}$ emissions from dung patches and control plots in our study. The $\mathrm{CO}_{2}$ emissions peak from fresh dung soils was greater immediately after application than from the control probably because the soil microbial respiration rate was stimulated by additional substrate in the soil (Kelliher et al., 2005).

Urea in animal urine undergoes hydrolysis and is catalysed by the enzyme urease and increased soil solution $\mathrm{pH}$, dissolved organic carbon and total dissolved phosphorus concentrations (Shand et al., 2000), so microbial activity was increased in urine patches, thus stimulating $\mathrm{CO}_{2}$ emissions. Lee et al. (2002) reported that post-rainfall events increased soil $\mathrm{CO}_{2}$ fluxes, but this was not determined in our study.

\section{Cumulative $\mathrm{CO}_{2}-\mathrm{C}$ equivalent emission}

During the 55-d experiment, in sheep excrement plots (1.2\%) $\mathrm{CH}_{4}$ flux was $0.02 \%$ of non-excrement areas (98.8\%). Compared with the control, cumulative $\mathrm{CH}_{4}$ consumption decreased 25.7 and 33.3\% from urine and dung plots, respectively. Cumulative $\mathrm{CO}_{2}$ emissions increased 0.9 and $15.9 \%$ from urine and dung plots, respectively. In this study, sheep excrement weakened $\mathrm{CH}_{4}$ intake and increased $\mathrm{CO}_{2}$ emissions. Although the other GHG effects (e.g. nitrous oxide) were not considered, livestock excreta has the potential to contribute to global warming in the Inner Mongolia desert grassland.

\section{ACKNOWLEDGEMENTS}

This research was supported by the Chinese National Natural Science Foundation (30960072, 31160109), National Commonweal Project (200903060, 201003019), and Inner Mongolia Palmary Youth Project (2011JQ04). The authors gratefully acknowledge the technical assistance of X. Z. Ma and S. P. Wang. We also thank the staff at the research station for their care of the sheep and collection of urine and feces.

\section{REFERENCES}

Bauer, J., M. Herbst, J. A. Huisman, L. Weihermuller and H. Vereecken. 2008. Sensitivity of simulated soil heterotrophic respiration to temperature and moisture reduction functions. Geoderma 145:17-27.

Billings, S. A. and S. E. Ziegler. 2008. Altered patterns of soil carbon substrate usage and heterotrophic respiration in a pine forest with elevated $\mathrm{CO}_{2}$ and $\mathrm{N}$ fertilization. Glob. Chang. Biol. 14:1025-1036.

Bol, B., S. O. Peterson, C. Chrifttes, K. Dittert and M. N. Hansen. 2004. Short-term $\mathrm{N}_{2} \mathrm{O}, \mathrm{CO}_{2}, \mathrm{NH}_{3}$ fluxes, and N/C transfer in a Danish grass-cover pasture after simulated urine deposition in autumn. J. Plant Nutr. Soil Sci. 167:568-576.

Cardenas, L. M., D. Chadwick, D. Scholefield, R. Fychan, C. L. Marley, R. Jones, R. Bol, R. Well and A. Vallejo. 2007. The effect of diet manipulation on nitrous oxide and methane emission from manure application on incubated grassland soils. Atmos. Environ. 41:7096-7107.

Chadwick, D. R. and B. F. Pain. 1997. Methanduxes following slurry applications to grassland soils: laboratory experiments. Agric. Ecosyst. Environ. 63:51-60.

Cheng, X. L., R. H. Peng, J. Q. Chen, Y. Q. Luo, Q. F. Zhang, S. Q. An, J. K. Chen and B. Li. 2007. $\mathrm{CH}_{4}$ and $\mathrm{N}_{2} \mathrm{O}$ emissions from Spartina alterniflora and Phragmites australis in experimental mesocosms. Chemosphere 68:420-427.

Clemens, J. and H. J. Ahlgrimm. 2001. Greenhouse gases from animal husbandry: mitigation options. Nutr. Cycl. Agroecosyst. 60:287-300.

Flessa, H. and F. Beese. 2000. Laboratory estimates of trace gas 
emissions following surface application and injection of cattle slurry. J. Environ. Qual. 29:262-268.

Flessa, H., P. Dorscb, F. Beese, H. Konig and A. F. Bouwman. 1996. Influence of cattle wastes on nitrous oxide and methane fluxes in pasture land. J. Environ. Qual. 25:1366-1370.

Geng, Y. B., S. Zhang, Y. S. Dong, W. Q. Meng, Y. C. Qi, Z. Z. Chen and Y. F. Wang. 2001. The content of soil organic carbon and total nitrogen and correl ativity between their content and fluxes of $\mathrm{CO}_{2}, \mathrm{~N}_{2} \mathrm{O}$ and $\mathrm{CH}_{4}$ in Xilin River basin steppe. Acta Geogr. Sin. 56:44-53.

Gulledge, J. and J. P. Schimel. 2000. Controls on soil carbon dioxide and methane fluxes in a variety of Taiga forest stands in interior Alaska. Ecosystems 3:269-282.

Hart, S. C. 2006. Potential impacts of climate change on nitrogen transformations and greenhouse gas fluxes in forests: a soil transfer study. Glob. Change Biol. 12:1032-1046.

Haynes, R. J. and P. H. Williams. 1992. Changes in soil solution composition and $\mathrm{pH}$ in urine-affected areas of pasture. J. Soil Sci. 43:323-334.

Haynes, R. J. and P. H. Williams. 1993. Nutrient cycling and soil fertility in the grazed pasture ecosystem. Adv. Agron. 49:119199.

Husted, S. 1994. Seasonal-variation in methane emission from stored slurry and solid manure. J. Environ. Qual. 23:585-592.

IPCC. 2001. Climate Change 2001: The SciefitiBasis. Paris, France.

Kaharabata, S. K., P. H. Schuepp and R. L. Desjardins. 1998. Methane emissions from above ground open manure slurry tanks. Global Biochem. Cycle 12:545-554.

Kelliher, F. M., M. M. Barbour and J. E. Hunt. 2005. Sucrose application, soil microbial respiration and evolved carbon dioxide isotope enrichment under contrasting land uses. Plant Soil 268:233-242.

Kulling, D. R., H. Menzi, F. Sutter, P. Lischer and M. Kreuzer. 2003. Ammonia, nitrous oxide and methane emissions from differently stored dairy manure derived from grass- and haybased rations. Nutr. Cycl. Agroecosyst. 65:13-22.

Lee, M. S., K. Nakane, T. Nakatsubo, W. H. Mo and H. Koizumi. 2002. Effects of rainfall events on soil $\mathrm{CO}_{2}$ flux in a cool temperate deciduous broad-leaved forest. Ecol. Res 17:401409.

Lin, X. W., S. P. Wang, X. Z. Ma, G. P. Xu, C. Y. Luo, Y. N. Li, G. M. Jiang and Z. B. Xie. 2009. Fluxes of $\mathrm{CO}_{2}, \mathrm{CH}_{4}$, and $\mathrm{N}_{2} \mathrm{O}$ in an alpine meadow affected by yak excreta on the QinghaiTibetan plateau during summer grazing periods. Soil Biol. Biochem. 41:718-725.

Lovell, R. D. and S. C. Jarvis. 1996. Effect of cattle dung on soil microbial biomass $\mathrm{C}$ and $\mathrm{N}$ in a permanent pasture soil. Soil Biol. Biochem. 28:291-299.

Ma, X. Z., S. P. Wang, Y. F. Wang, G. M. Jiang and P. Nyren. 2006. Short-term effects of sheep excrement on carbon dioxide, nitrous oxide and methane fluxes in typical grassland of Inner Mongolia. NZ. J. Agric Res. 49:285-297.
Massé, D. I., F. Croteau, N. K. Patni and L. Masse. 2003. Methane emissions from dairy cow and swine manure slurries stored at $10^{\circ} \mathrm{C}$ and $15^{\circ} \mathrm{C}$. Can. Biosyst. Eng. 45:6.1-6.6.

Muhammad, F. I., Y. F. Cheng, W. Y. Zhu and Z. Basit. 2008. Mitigation of ruminant methane production: current strategies, constraint and future options. World J. Microbiol. Biotechnol. 24:2747-2755.

Park, K. H., A. G. Thompson, M. Marinier, K. Clark and C. Wagner-Riddle. 2006. Greenhouse gas emissions from stored liquid swine manure in a cold climate. Atmos. Environ. 40:618-627.

Pei, Z. Y., H. OuYang, C. P. Zhou and X. L. Xu. 2003. Fluxes of $\mathrm{CO}_{2}, \mathrm{CH}_{4}$ and $\mathrm{N}_{2} \mathrm{O}$ from alpine grassland in the Tibetan Plateau. Ecol. Environ. 13:27-34.

Petersen, S. O., S. Stamatiadis and C. Chrisfirales. 2004. Short term nitrous oxide emissions from pasture soil as influenced by urea level and soil nitrate. Plant Soil 267:117-127.

Roland, B., O. P. Soren, C. Calliopi, D. Klaus and N. H. Martin. 2004. Short-term $\mathrm{N}_{2} \mathrm{O}, \mathrm{CO}_{2}, \mathrm{NH}_{3}$ fluxes, and $\mathrm{N} / \mathrm{C}$ transfers in a Danish grass-clover pasture after simulated urine deposition in autumn. J. Plant Nutr. Soil Sci. 167:568-576.

Saggar, S., N. S. Bolan, R. Bbandral, C. B. Hedley and J. Luo. 2004. A review of emissions of methane, ammonia, and nitrous oxide from animal excreta deposition and farm effluent application in grazed pastures. NZ. J. Agric. Res. 47:513-544.

Shand, C. A., B. L. Williams, S. Smith and M. E. Young. 2000. Temporal changes in $\mathrm{C}, \mathrm{P}$ and $\mathrm{N}$ concentrations in soil solution following application of synthetic sheep urine to a soil under grass. Plant Soil 222:1-13.

Shand, C. A., L. A. Williams, L. A. Dawson, S. Smith and M. E. Young. 2002. Sheep urine affects soil solution nutrient composition and roots: differences between field and sward box soils and the effects of spithetic and natural sheep urine. Soil Biol. Biochem. 34:163-171.

Simona, C. and F. Angelo. 2005. Soil-atmosphere methane exchange in undisturbed and burned Mediterranean shrubland of southern Etaly. Ecosystems 8:182-190.

SPSS for Windows. 2003 Release 13.0 Copyright $^{\odot}$, (2003), SPSS Inc., Chicago.

Wang, Y. S. and Y. H. Wang. 2003. Quick measurement of $\mathrm{CH}_{4}$, $\mathrm{CO}_{2}$ and $\mathrm{N}_{2} \mathrm{O}$ emission from a short-plant ecosystem. Adv. Atmos. Sci. 20:842-844.

Wang, Z. P., Y. Song, J. Gulledge, Q. Yu, H. S. Liu and X. G. Han. 2009. China's grazed temperate grasslands are a net source of atmospheric methane. Atmos. Environ. 43:2148-2153.

Williams, R. H. and R. J. Haynes. 1994. Comparison of initial wetting pattern, nutrient concentrations in soil solution and the fate of ${ }^{15} \mathrm{~N}$-labelled urine in sheep and cattle urine patch areas of pasture soil. Plant Soil 162:49-59. 